\title{
Use of clearance rate in Choromytilus chorus (Bivalvia: Mytilidae) as a non-destructive biomarker of aquatic pollution
}

\author{
El uso de la tasa de aclaramiento en Choromytilus chorus (Bivalvia: Mytilidae) como \\ biomarcador no destructivo de la polución acuática
}

BEATRIZ TORO ${ }^{1,2}$, JORGE M. NAVARRO ${ }^{1}$ \& HERNÁN PALMA-FLEMING ${ }^{3}$

\author{
${ }^{1}$ Instituto de Biología Marina “Dr. Jürgen Winter”, Universidad Austral de Chile, \\ Casilla 567, Valdivia, Chile; e-mail: jnavarro@uach.cl \\ ${ }^{2}$ Present address: Corporación Ambiental, Universidad de Antioquia, AA 1226, Medellín, Colombia; \\ e-mail: btoro@udea.edu.co; \\ ${ }^{3}$ Instituto de Química, Universidad Austral de Chile, Casilla 567, Valdivia, Chile; \\ e-mail:palma@uach.cl
}

\begin{abstract}
Reduction in clearance rate was observed in the mussel Choromytilus chorus in relation to the degree of environmental pollution. Three sampling sites included the polluted San Vicente Bay, middling polluted Corral Bay, and weakly polluted Yaldad Bay in southern Chile. Pollution levels were estimated by quantitative analysis of polynuclear aromatic hydrocarbons (PAHs) in mussel tissue from the three sites. Mussels from San Vicente showed lowest clearance rates and highest PAHs levels in both spring 1998 and summer 1999. Populations from Corral and Yaldad showed generally low levels of PAHs, so the mussels from Yaldad showed the highest rates of clearance in comparison to Corral and San Vicente populations. The significant negative relationship $(\mathrm{P}<0.001)$ demonstrated between tissue pollution of the mussels and their clearance rates argues for the usefulness of the method employing a non-destructive biomarker in evaluation of the impact of environmental pollution on marine species.
\end{abstract}

Key words: Choromytilus chorus, clearance rate, PAHs, biomarker, environmental monitoring.

\section{RESUMEN}

Se observó un deterioro de la tasa de aclaramiento en Choromytilus chorus de acuerdo al grado de polución ambiental. Se incluyeron tres sitios de muestreos, la bahía de San Vicente muy contaminada, la bahía de Corral con una polución intermedia y la bahía de Yaldad, al sur de Chile, con una baja contaminación. Los niveles de polución fueron estimados por análisis cuantitativos de hidrocarburos aromáticos polinucleares (HAPs) en el tejido de los choros zapatos de los tres sitios de muestreo. Los choros zapatos de San Vicente mostraron la menor tasa de aclaramiento y altos niveles de HAPs, tanto en la primavera de 1998 como en el verano de 1999. Las poblaciones de Corral y Yaldad mostraron en general bajos niveles de HAPs, en tanto que los ejemplares de Yaldad presentaron altas tasas de aclaramiento en comparación con las poblaciones de Corral y San Vicente. La relación negativa significativa $(\mathrm{P}<0,001)$ entre la polución en el tejido de los choros zapatos y sus tasas de aclaramiento, argumenta la utilidad del método como un biomarcador no destructivo para evaluar el impacto ambiental de la polución en las especies marinas.

Palabras clave: Choromytilus chorus, tasa de aclaramiento, HAPs, biomarcadores, monitoreo ambiental.

\section{INTRODUCTION}

In recent years, the search has intensified for innovative study methods for evaluation and detection of the impacts of man's activities relative to pollution of aquatic organisms in order to promote design and implementation of preventive measures. The developing field of Ecotoxicology has provided new methodological focus, based on physiological, biochemical, or molecular responses that an organism, population, or community may reflect under the threat of potential chemical, physical, or biological danger (EHC 1993). Each of these responses or biomarkers represent an integrated signal of the pollution level in a given area, and thus an indicator of the toxicological risk to which a natural population of organisms may be submitted (Bayne et al. 1985). The greatest strength of the biomarkers lies in their capacity for avoiding the serious limitations of classical estimations of environmental toxicology such as the measurement of chemical residues in organisms or envi- 
ronmental samples, and to relate acute effects by using toxicity testing (Weeks 1998).

The biomarkers, especially those which are physiological and nonspecific, have been widely used in the laboratory to document and quantify levels of exposure as well as the effects of environmental pollutants on organisms. For exposure monitoring, the biomarkers have the advantage of rapidly reacting to the exposure and thus uniquely quantify presence of biologically available pollutants, and as monitors of effects, they are able to integrate the effects of multiple stress factors (Bayne et al. 1985, Weeks 1998).

The use of new non-destructive biomarkers is important for animal studies, because they may be designed to reduce the number of animals used and to minimize pain and distress, and for the hazard assessment and conservation of endangered species such as marine mammals. As animal testing represents the primary basis for reliable assessment and management of chemical risk, the rationale of alternative testing is to minimize as far as possible, the use of vertebrates in testing procedures, particularly by the use of lower organisms as a substitute for vertebrates (Fossi \& Marsili 1997, Walker 1998b in Repetto et al. 2000).

Invertebrate species were used primarily as true indicator organisms on the basis of abundance, sampling facility, and wide spectrum of ecological characteristics and sensitivity to chemicals. The use of invertebrates as bioindicators or bioaccumulators was therefore implemented before that of vertebrates, but their application was marginal and primarily involved developmental toxicity and genotoxicity testing. More recent investigations have clearly highlighted the interest in using invertebrates to link individual responses with changes in populations or communities, as such correlations will be of great value for rapid, early warning assessment of the environmental impact of chemicals (Repetto et al. 2000).

Sublethal alterations in the physiology of bivalves, principally mytilids, have been used in the evaluation of pollution. Bivalves are able to accumulate numerous chemical compounds in their tissues, which directly or indirectly may produce significant impacts on their biology (Martin et al. 1984, Widdows et al. 1987, Widdows \& Johnson 1988, Widdows et al. 1997). The structural and functional role of bivalves within a community or ecosystem are fundamentally affected by their physiological processes such as feeding, respiration, excretion, and growth (Dame 1996). Among the physiological responses of bivalves, clearance rate is one of the most important since it not only is related to the acquisition of energy necessary for vital functions, but is also sensitive to environmental changes such as organic pollutants (Axiak \& George 1987b, Axiak et al. 1988, Bayne \& Thurberg 1988, Sunila 1988, Livingstone \& Pipe 1992).

In the present study, the clearance rate of Choromytilus chorus was evaluated in individuals obtained from populations exposed to different degrees of pollution, and the aromatic hydrocarbon content of their soft tissues was analyzed as a quantitative measure of their exposure to pollutants. These methods were applied with the objective of encountering a nondestructive biomarker which could be used to a low level of organization within the ecosystem as a potentially rapid measure having ecological significance.

\section{MATERIAL AND METHODS}

Three areas, each exposed to a different level of pollution, and separated from each other by 400 $\mathrm{km}$, were established for collection of test specimens of $C$. chorus (Fig.1). Two samplings were carried out at each test site, one in spring 1998 and a second during summer 1999. Site A, considered to be highly polluted, was located in San Vicente Bay $\left(36^{\circ} 44^{\prime} \mathrm{S}, 7^{\circ} 09^{\prime} \mathrm{W}\right)$ near steel, petrochemical, and fish processing industries. Site $\mathrm{B}$, with intermediate pollution, was in Corral Bay $\left(39^{\circ} 52^{\prime} \mathrm{S}, 73^{\circ} 25^{\prime} \mathrm{W}\right)$ near a fishing port and a small town. Site C, with low pollution levels, was located on Yaldad Bay $\left(43^{\circ} 08^{\prime} \mathrm{S}, 73^{\circ} 44^{\prime} \mathrm{W}\right)$ on the Chiloé Island, where the main economic activity is massive culture of the mussel Mytilus chilensis.

Choromytilus chorus was collected by diving at $8 \mathrm{~m}$ depth in natural banks at San Vicente and Corral Bays, while at Yaldad the specimens were obtained from hanging cultures at 4-8 m depth. All specimens were transported to the laboratory under wet conditions, at temperatures near to those at the collection site. For each in vivo measurement, 15 individuals were randomly selected and kept in seawater at a salinity of $30 \%$, and temperatures of $12{ }^{\circ} \mathrm{C}$ (spring) or $15{ }^{\circ} \mathrm{C}$ (summer). They were fed daily with laboratory cultured Isochrysis galbana at $20 \times 10^{6}$ cell L-1. Prior to physiological measurements the shells were cleaned of epibionts, and placed in $6 \mathrm{~L}$ aerated seawater aquaria for acclimation periods of 12 to $48 \mathrm{~h}$ (Widdows 1993). 
Chemical analyses of tissues

PAHs were analyzed on pooled (15-20 specimens) C. chorus from each of the three sampling sites during spring 1998 and summer 1999. The shells of the mussels were removed and the whole tissue homogenized. Standard operation procedures on sample handling and preparation followed guidelines of FAO/SIDA (1983) which included freezing storage of tissues at $-18{ }^{\circ} \mathrm{C}$ until analysis. Homogenized subsamples (10 g) were Soxhlet extracted and cleaned as described

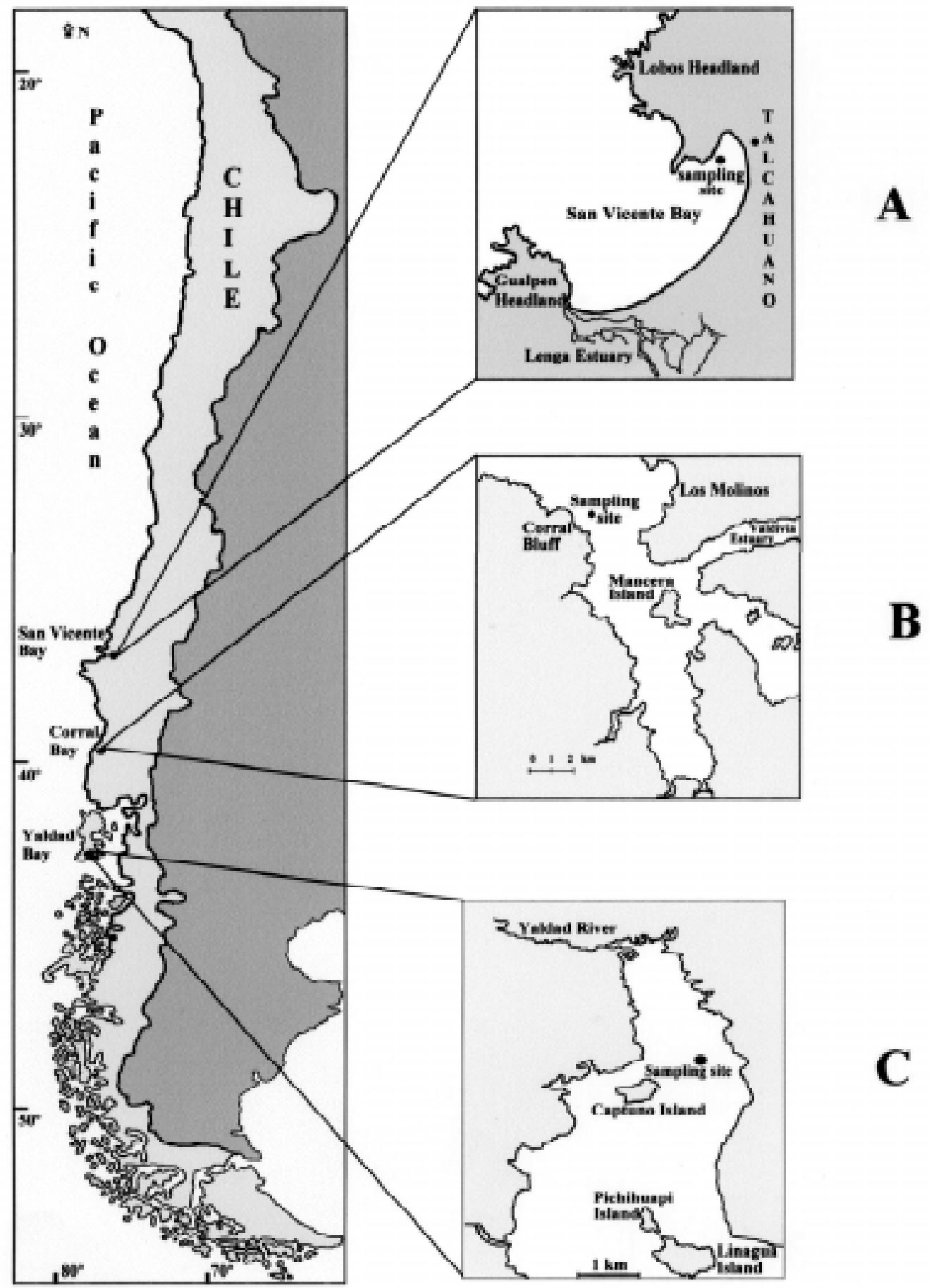

Fig. 1: Sampling sites: (A) San Vicente Bay; (B) Corral Bay; (C) Yaldad Bay. Sitios de muestreo: (A) Bahía de San Vicente; (B) Bahía de Corral; (C) Bahía de Yaldad. 
by UNEP (1992). Perylene as internal standard was added to all samples. Analytical methodology was tested on Standard Reference Material (SRM 2974) containing 14 PAHs at known concentrations in mussel tissue (Mytilus edulis), obtained from the National Institute of Standards and Technology (NIST), Gaithersburg, MD, USA. PAHs recoveries varied between $65-115 \%$ in certified mussel tissue SRM 2974 (NIST) by spiking the samples with perdeuterated PAHs: Phenanthrene $\mathrm{d}_{10}$, Chrysene $\mathrm{d}_{12}$, Acenaphthene $\mathrm{d}_{10}$, Perilene $d_{12}$. Four analytical replicates were done for each sampling site per season.

PAHs were identified and quantified by using a HP 6980 (Hewlett Packard) gas chromatograph equipped with HP 5973A mass selective detector. A capillary column HP-5 (Hewlett Packard) of 30 $\mathrm{m} \times 0.25 \mathrm{~mm}$ inner diameter $\times 0.25 \mu \mathrm{m}$ film thickness was used. Temperature was programmed at $70{ }^{\circ} \mathrm{C}$ for $4 \mathrm{~min}$, followed by $10^{\circ} \mathrm{C}$ per min to $300^{\circ} \mathrm{C}$ and then hold 9 min.

Quantification of the PAHs was carried out using a five-point calibration curve containing $80,60,40,25$ and $10 \mu \mathrm{g} \mathrm{mL}^{-1}$ of a mixture of 16 PAHs (TLC Polynuclear Aromatic Hydrocarbons Mix, SUPELCO Corp.). The Estimated Detection Limit (EDL) of the analytical method was $5 \mu \mathrm{g}$ $\mathrm{kg}^{-1}$ dry tissue for $10 \mathrm{~g}$ sample.

\section{Physiological measurements}

Three replicates of the diet (I. galbana) supplied to the mussels were analyzed to determine contents of inorganic and organic material. Samples were concentrated on $47 \mathrm{~mm}$ diameter GF/C tared filters with a pore diameter of $0.75 \mu \mathrm{m}$ and then washed with isotonic ammonium formate solution. The filters were dried at $60{ }^{\circ} \mathrm{C}$ for $48 \mathrm{~h}$, and then analytically weighed to calculate total dry weight of particulate material per $\mathrm{L}$ of seawater. The filters were then ashed at $450{ }^{\circ} \mathrm{C}$ for $3 \mathrm{~h}$ to determine the organic fraction of the diet.

Food consumption is normally measured in terms of clearance rate $(\mathrm{CR})$ defined as the volume of water cleared of particles greater than 4 $\mu \mathrm{m}$ in diameter per unit time (h) at a retention efficiency of $100 \%$ (Bayne et al.1985). The CR of mussels in the present study was measured in a static system using the methods of Bayne et al. (1985). Specimens were tested in $6 \mathrm{~L}$ seawater aquariums. In addition to the 15 aquaria per sampling site, a control aquarium was run without test organisms to control for sedimentation or multiplication of the food algae. Food algae were added at a concentration of $20 \times 10^{6} \mathrm{cell} \mathrm{L}^{-1}$. All aquarium were fitted with compressed air bubblers to assure uniform mixing.

One specimen of $C$. chorus was added to each aquarium and allowed $30 \mathrm{~min}$ for acclimation to the system, in which the mussel opened its valves and showed normal filtering behavior. The CR was determined seven times at $30 \mathrm{~min}$ intervals by collecting $20 \mathrm{~mL}$ aliquots of seawater from each test aquarium and from the control. Algal cell concentrations were measured in the test samples using an ELZONE $180 \mathrm{XY}$ particle counter equipped with a $120 \mu \mathrm{m}$ counting tube. The CR was determined according to the following relation:

$$
\mathrm{CR}=\mathrm{V}\left(\log _{\mathrm{e}} \mathrm{C}_{1}-\log _{\mathrm{e}} \mathrm{C}_{2}\right) / \mathrm{t}
$$

where $\mathrm{CR}=$ clearance rate, $\mathrm{V}=$ volume, $\mathrm{C} 1$ and $\mathrm{C} 2$ = concentrations of particles at the beginning and ending of time interval t.

\section{Statistical analyses}

Since data did not comply with the hypothesis of analysis of variance (ANOVA) since they did not show a normal distribution, and because their variances were not homoscedastic, the non-parametric Mann-Whitney U-test was employed (Sokal $\&$ Rohlf 1979). Comparisons were made between CR values obtained of $C$. chorus from the three test sites for both spring and summer sampling periods.

The correlation between the CR of C. chorus and tissue PAHs concentration was determined using a Spearman multiple correlation matrix (Sokal \& Rohlf 1979).

\section{RESULTS AND DISCUSSION}

\section{Polynuclear aromatic hydrocarbons}

PAHs concentrations obtained for mussel specimens from San Vicente Bay during both sampling seasons were significantly higher than those detected in populations from Corral and Yaldad (Fig. $2)$. Significant $(P<0.005)$ differences were found between populations of $C$. chorus among compounds detected in the tissues from the three bays, except between Corral and Yaldad in the spring. Significant seasonal differences $(\mathrm{P}<0.05)$ were observed just between populations from Corral Bay. The most relevant compounds (Anthracene and Phenanthrene) found in C. chorus from Yaldad and Corral Bays were in high concentrations both in spring and summer, whereas in San Vicente Bay 


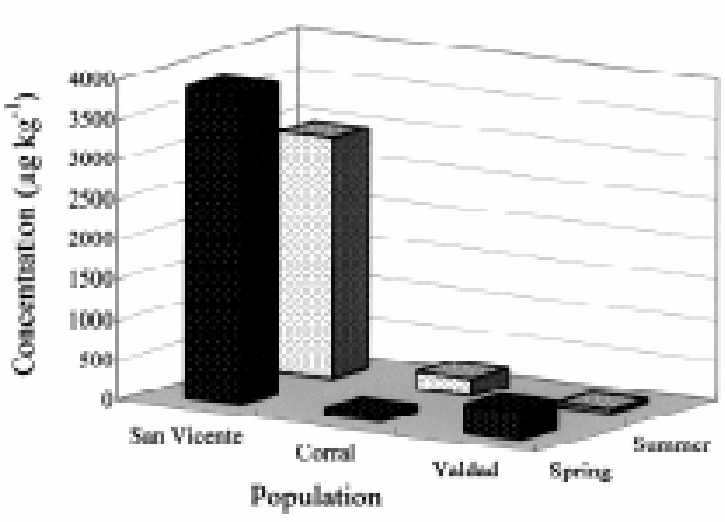

Fig. 2: Concentration of total PAHs in tissue of C. chorus during spring 1998 and summer 1999.

Concentración de HAPs totales en tejido de C. chorus durante la primavera de 1998 y el verano de 1999.

were found Benzo (k) fluoranthene and Pyrene at higher relative levels (Table 1).

\section{Clearance rate}

During spring $C$. chorus from San Vicente Bay had clearance rates significantly lower than those from Corral $(P<0.005)$ and Yaldad $(P<0.0005)$, with a mean value of $0.67 \mathrm{~L} \mathrm{~h}^{-1} \mathrm{~g}^{-1}$, which represented 42 and $48 \%$ of the clearance rates found for individuals from Corral and Yaldad, respectively. During summer, individuals from San Vicente showed no significant differences in CR from those of Corral, but they were different from those of Yaldad $(\mathrm{P}<0.001)$ with a mean value of $0.97 \mathrm{~L} \mathrm{~h}^{-1} \mathrm{~g}^{-1}$. This represented a $43 \%$ of the

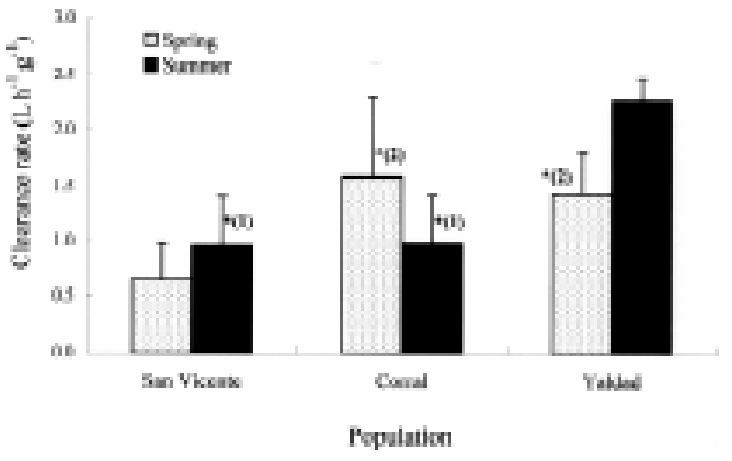

Fig. 3: Clearance rate $\left(\mathrm{L} \mathrm{h}^{-1} \mathrm{~g}^{-1}\right)$ in C. chorus during spring and summer. The values represent means \pm one SD, $\mathrm{n}=15 ;(*)$ indicates absence of statistically significant difference, and numbers in ( ) indicate between which populations.

Tasa de aclaramiento $\left(\mathrm{L} \mathrm{h}^{-1} \mathrm{~g}^{-1}\right)$ en $C$. chorus durante primavera y verano. Los valores corresponden a promedios \pm una DE; $n=15 ;(*)$ indica ausencia de diferencias estadísticamente significativas, y el número en ( ) indica entre cuales poblaciones.

clearance rate measured on mussels from Yaldad (Fig. 3). The Spearman correlation matrix showed a significant negative correlation between the clearance rate and concentration of PAHs in the tissues, with an $\mathrm{r}$ value of $-0.82(\mathrm{P}=0.001)$ in spring and $-0.79(\mathrm{P}=0.001)$ in summer (Fig. 4).

Chronic or acute exposures of marine organisms to toxic substances may produce deleterious biochemical or biological changes. The clearance rates in individuals from San Vicente Bay gave lower values for CR when compared with those presented by Navarro (1988) for individuals of the same species measured from the Queule River estuary $\left(1.56 \mathrm{~L} \mathrm{~h}^{-1} \mathrm{~g}^{-1}\right)$. The specimens from $\mathrm{San}$ Vicente Bay showed reductions of 57-52\% when

TABLE 1

Concentrations of common PAHs ( $\left.\mu \mathrm{g} \mathrm{kg} \mathrm{dry} \mathrm{wt}^{-1}\right)$ in C. chorus during spring 1998 and summer 1999; $(\mathrm{n}=4)$

Concentración de HAPs comunes $\left(\mu \mathrm{g} \mathrm{kg} \mathrm{dry} \mathrm{wt}^{-1}\right)$ en $C$. chorus durante la primavera de 1998 y el verano 1999; $(\mathrm{n}=4)$

\begin{tabular}{|c|c|c|c|c|c|c|}
\hline \multirow[t]{2}{*}{ PAHs } & \multicolumn{5}{|c|}{ Population } & \\
\hline & A & $\mathrm{B}$ & A & $\mathrm{B}$ & A & B \\
\hline Phenanthrene & 80 & 231 & 24 & 45 & 149 & 13 \\
\hline Anthracene & 88 & 96 & 21 & 92 & 49 & 12 \\
\hline Pyrene & 221 & 309 & 5 & 5 & 25 & 6 \\
\hline Benzo(k)fluoranthene & 130 & 168 & 8 & 24 & 6 & 6 \\
\hline
\end{tabular}

(A) = spring sampling, 1998

(B) = summer sampling, 1999 
compared with populations from Corral and Yaldad Bays, which was a much higher percentage than that obtained by Widdows et al. (1982) who recorded CR reductions of 15 to $20 \%$ in Mytilus edulis exposed to $30 \mu \mathrm{g} \mathrm{L}^{-1}$ of hydrocarbons above control values.

The high degree of negative correlation obtained between the concentrations of PAHs in tissues of $C$. chorus and the clearance rates suggested that these organic pollutants might be exerting a deleterious effect on this physiological response, and that the degree of stress was a function of the levels of these xenobiotic chemicals in tissues of the organism. Several ecotoxicological studies have shown that the clearance rate is the component of the energy budget most affected by toxic compounds (Howell et al. 1984, Axiak \& George 1987a, Capuzzo 1988, Widdows \& Johnson 1988, Bourdelin 1996), principally saturated hydrocarbons with low boiling points (ITSEMAP 1994). A detailed study of the effects of hydrocarbons on the gills of Venus verrucosa carried out by Axiak \& George (1987b) showed that exposure to these compounds reduced the pumping activity of the lateral cilia, as well as interference with normal beating of the eulaterofrontal cirri, resulting in a decrease in the rate of clearance rate. Axiak \& George (1987b) indicate that long-term exposure to low concentrations of water-accommodated-fractions of oil may lead to significant reductions in retention efficiencies of particles less than 6 to $8 \mu \mathrm{m}$ in diameter. This result may be considered of significant ecological importance since it implies that exposed individuals will be able to feed less on the normally abundant, naturally occurring food particles below this size range.

Therefore, these compounds exert a narcotizing effect on ctenidial cilia or may produce morphological alterations of branchial filaments or severe perturbations in ciliated epithelial cells (Auffret 1988). It has been suggested that the decrease in filtering rate in bivalves may be due to the inhibitory effects produced by hydrocarbons on the cilia involved with feeding (Bayne et al. 1982) by affecting the $\mathrm{Mg}^{++}$ATPase in the plasma membrane, which provides the energy necessary for generation of ciliary movement, and thus transport of water over the gill (Stekoll et al. 1980).

Significant decreases in clearance rate due to increases in pollutant levels have been observed in other field and laboratory studies, such as in the case of the bivalves Arca zebra (Widdows et al. 1990), Macoma balthica (Stekoll et al. 1980), Modiolus demissus (Gilfillan 1975), Mytilus edulis

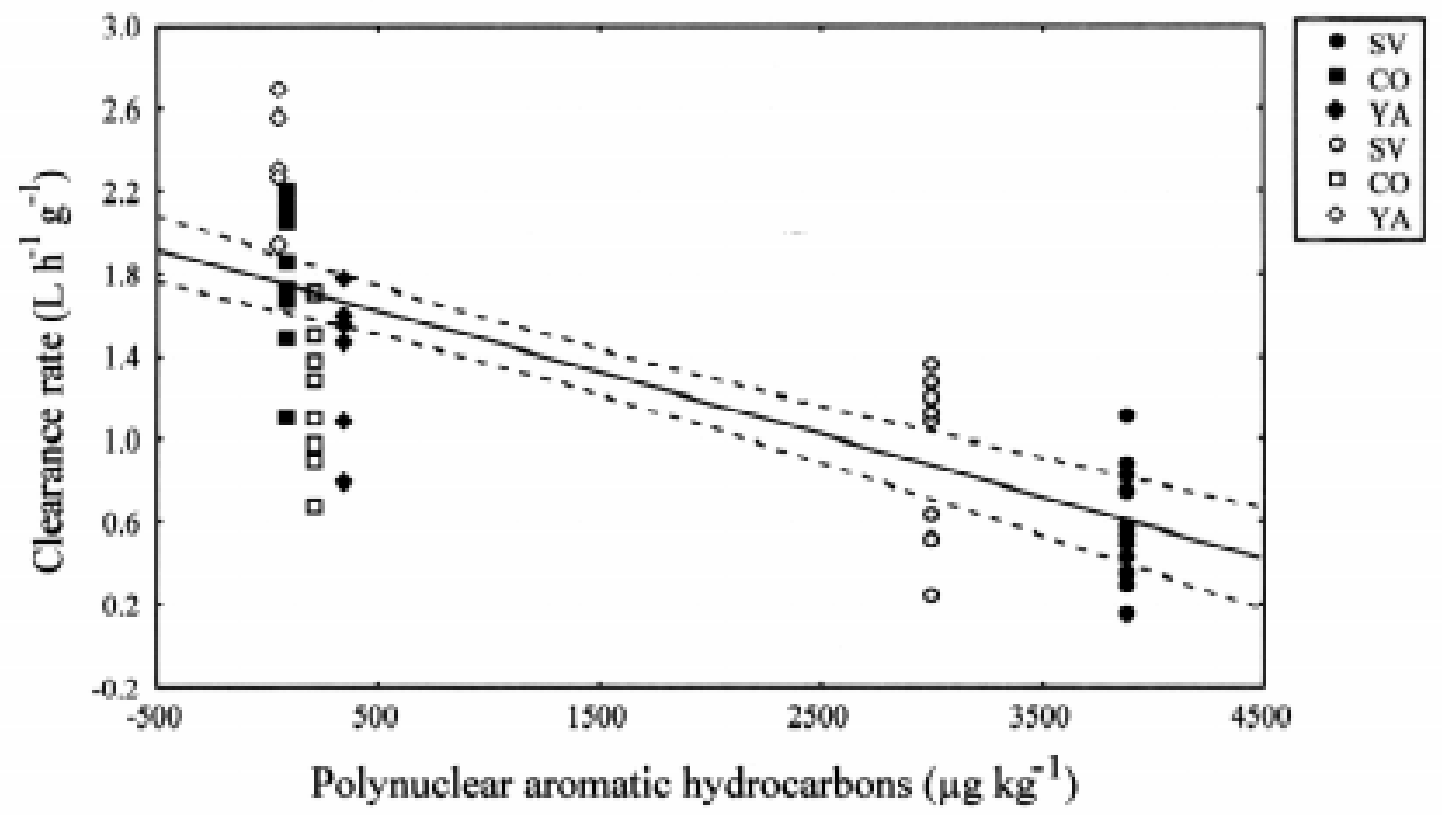

Fig. 4: Correlation between the clearance rate and PAHs concentration in C. chorus in populations in San Vicente (SV), Corral (CO) and Yaldad (YA). Dark symbols are for spring whereas light symbols are for summer data; $\mathrm{n}=70$.

Correlación entre la tasa de aclaramiento y la concentración de HAPs en poblaciones de C. chorus en San Vicente (SV), Corral (CO) y Yaldad (YA). Los símbolos negros corresponden a los valores de primavera mientras que los blancos a los de verano; $\mathrm{n}=70$. 
(Martin et al. 1984, Widdows \& Johnson 1988), Venus verrucosa (Axiak \& George 1987b) y Crassostrea virginica (Stegeman \& Teal 1973). Similar results were also obtained for the gastropod Thais lima (Stickle et al. 1984). Low molecular weight polycyclic aromatic hydrocarbons form the most toxic fraction of petroleum (Blumer et al. 1970). According to the quantitative structureactivity relationship (QSAR) of some organic compounds, estimations have been made quantifying the relationships between the presence of hydrocarbons and reduction in filtration rates. For example, concentrations of $100 \mu \mathrm{g} \mathrm{g}^{-1}$ dry tissue of 1-3 ring aromatic hydrocarbons may produce a $50 \%$ reduction in clearance rate when the octanol-water partition coefficient $\left(\mathrm{K}_{\mathrm{ow}}\right)$ of the hydrocarbons is less than five. While, PAHs (> 4 rings) with higher $\mathrm{K}_{\mathrm{ow}}$ (5-6) may be accumulated in greater quantities before they produce toxic effects (Donkin et al. 1989, Widdows et al. 1990, Donkin et al. 1991, Widdows \& Salked 1992). In view of the preceding, the decline in clearance rate in C. chorus may be due in part to the presence of tri- and tetra- aromatic PAHs which were detected at high concentrations in mussels from San Vicente Bay (Table 1).

Based on the literature and the present results obtained, the clearance rate may be considered as a convenient, non-destructive biomarker useful in evaluation of the effects of pollution because: (1) The response time to the pollutant is relatively short; (2) The signal of the pollution effect is sufficiently high so as to be differentiated from «noise» of natural variability since the bivalves show a good deal of plasticity with regard to extrinsic factors; (3) The parameter can be precisely measured, and is sensitive to environmental changes produced by man; (4) The organismic response is simply interpreted as adverse or beneficial; and (5) The results obtained are ecologically relevant, since the decrease in clearance rate may have adverse effects on growth, reproduction, and survival of the species, so their potential capacity is affected to contribute with descendant, what harms the population and ultimately, to the well-being of the community. However, the PAHs are not the only organic compounds which reduce clearance rates in mussels, and caution is needed in interpreting this physiological response.

\section{ACKNOWLEDGEMENTS}

The authors gratefully acknowledge to the staff of the field station of Yaldad, Chiloé (Universidad Austral de Chile), where most of the physiological measurements were done. This study was supported by a research grant to JMN (Program of Aquaculture and Marine Biotechnology, 1(97), FONDAP, Chile, Invertebrate Subprogram) and by a doctoral fellowship to B. Toro by DAAD (Deutscher Akademischer Austauschdienst, Programmabteilung Süd). Partial financing was also provided by the Office of Research and Development of the Universidad Austral de Chile (grant 1999203).

\section{LITERATURE CITED}

AUFFRET M (1988) Histopathological changes related to chemical contamination in Mytilus edulis from field and experimental conditions. Marine Ecology Progress Series 46: 101-107.

AXIAK V \& J GEORGE (1987a) Bioenergetics responses of the marine bivalve Venus verrucosa on long-term exposure to petroleum hydrocarbons. Marine Environmental Research 23: 33-47.

AXIAK V \& J GEORGE (1987b) Effects of exposure to petroleum hydrocarbons on the gill functions and ciliary activities of a marine bivalve. Marine Biology 94: 241-249.

AXIAK V, J GEORGE \& MN MOORE (1988) Petroleum hydrocarbons in the marine bivalve Venus verrucosa accumulation and cellular responses. Marine Biology 97: 225-230.

BAYNE BL \& FP THURBERG (1988) Physiological measurements on Nucula tenuis and on isolated gills of Mytilus edulis and Carcinus maenas. Marine Ecology Progress Series 46: 129-134.

BAYNE BL, J WIDDOWS, MN MOORE, P SALKED, CM WORRALL \& P DONKIN (1982) Some ecological consequences of the physiological and biochemical effects of petroleum compounds on marine molluscs. Philosophical Transactions of the Royal Society of London B 297: 219-239.

BAYNE BL, DA BROWN, K BURNS, DRM DIXON, A IVANOVICI, DR LIVINGSTONE, DM LOWE, MN MOORE, A STEBBING \& J WIDDOWS (1985) The effects of stress and pollution on marine animals. Praeger Publishers, New York, New York, USA. 384 pp.

BLUMER M, G SOUZA \& J SASS (1970) Hydrocarbon pollution of edible shellfish by an oil spill. Marine Biology 5: 195-202.

BOURDELIN F (1996) Physiological responses of the tropical mussels, Modiolus auriculatus a possible biological monitor in French Polynesia. Marine Pollution Bulletin 332: 480-485.

CAPUZZO JM (1988) Physiological effects of a pollutant gradient - Summary. Marine Ecology Progress Series 46: 147-148.

DAME RF (1996) Ecology of marine bivalves: an ecosystem approach. CRC Press, Boca Raton, Florida, USA, $254 \mathrm{pp}$.

DONKIN P, J WIDDOWS, SV EVANS \& MD BRINSLEY (1991) QSARs for the sublethal response of marine mussels (Mytilus edulis). The Science of the Total Environment 109/110: 461-476. 
DONKIN P, J WIDDOWS, SV EVANS, CM WORRAL \& M CARR (1989) Quantitative structure-activity relationship for the effect of hydrophobic organic chemicals on rate of feeding by mussels (Mytilus edulis). Aquatic Toxicology 14: 227-294.

EHC (1993) Biomarkers and risk assessment: concepts and principles. International Programme on Chemical Safety (IPCS), EHC No. 155, Geneva, Switzerland. $82 \mathrm{pp}$.

FAO/SIDA (1983) Manual de métodos de investigación del medio ambiente acuático. Parte 9. Análisis de metales y organoclorados en los peces. Documento Técnico de Pesca 212. 35 pp.

FOSSI MC \& L MARSILI (1997) The use of non destructive biomarkers in the study of marine mammals. Biomarkers 2: 205-216.

GILLFILLAN ES (1975) Decrease of net carbon flux in two species of mussels caused by extracts crude oil. Marine Biology 29: 53-58.

HOWELL R, AM GRANT \& NEJ MACCOY (1984) Effect of treatment with Reserpine on the change in filtration rate of Mytilus edulis subjected to dissolved copper. Marine Pollution Bulletin 15: 436-439.

ITSEMAP (1994) Manual de contaminación ambiental. Fundación MAPFRE, Madrid, Spain. 578 pp.

LIVINGSTONE D \& RK PIPE (1992) Mussels and environmental contaminants: molecular and cellular aspects. In: Gosling E (ed) The mussel Mytilus: ecology, physiology, genetics and culture: 425-464. Elsevier, Amsterdam, The Netherlands.

MARTIN M, G ICHIKAWA, J GOETZL, MDL REYES \& MD STEPHENSON (1984) Relationship between physiological stress and trace toxic substances in the bay mussel, Mytilus edulis, from San Francisco Bay, California. Marine Environmental Pollution Research 11: 91-110.

NAVARRO JM (1988) The effect of salinity on the physiological ecology of Choromytilus chorus (Molina, 1782) (Bivalvia: Mytilidae). Journal of Experimental Marine Biology and Ecology 122: 19-33.

REPETTO G, A DEL PESO \& M REPETTO (2000) Alternative ecotoxicological methods for the evaluation, control and monitoring of environmental pollution. Ecotoxicology and Environmental Restoration 3: 47-51.

SOKAL R \& F ROHLF (1979) Biometría: principios y métodos estadísticos en la investigación biológica. H. Blume Ediciones, Madrid, España. 832 pp.

Associate Editor: Patricio Ojeda

Received December 14, 2001; accepted January 15, 2003
STEGEMAN JJ \& JM TEAL (1973) Accumulation, release and retention of petroleum hydrocarbons by the oyster Crassostrea virginica. Marine Biology 22: 37-44.

STEKOLL MS, LE CLEMENT \& DG SHAW (1980) Sublethal effects of chronic oil exposure on the intertidal clam Macoma balthica. Marine Biology 57: 51-60.

STICKLE WB, SD RICE \& A MOLES (1984) Bioenergetics and survival of the marine snail Thais lima during long term oil exposure. Marine Biology 80: 281-289.

SUNILA I (1988) Acute histological responses of the gill of the mussel, Mytilus edulis to exposure by environmental pollutants. Journal of Invertebrate Pathology 52: $137-141$.

UNEP (1992) Determinations of petroleum hydrocarbons in sediments. Reference methods for marine pollution, Studies No. 20, Cedex, Monaco. 75 pp.

WEEKS JM (1998) Effects of pollutants on soil invertebrates: links between levels. In: Schüürmann G \& B Market (eds) Ecotoxicology: 645-664. John Wiley \& Sons Inc., New York, New York, USA.

WIDDOWS J (1993) Marine and estuarine invertebrate toxicity tests. In: Calow $P$ (ed) Handbook of ecotoxicology: 145-166. Blackwell Scientific Publications, London, United Kingdom.

WIDDOWS J \& D JOHNSON (1988) Physiological energetics of Mytilus edulis: scope for growth. Marine Ecology Progress Series 46: 113-121.

WIDDOWS J \& PN SALKELD (1992) Role of scope for growth in environmental toxicology and pollution monitoring. FAO/UNEP training workshop on: "the techniques for monitoring biological effects of pollutants on marine organism". Plymouth Marine Laboratory, Plymouth, United Kingdom. 31 pp.

WIDDOWS J, T BAKKE, BL BAYNE, P DONKIN, DR LIVINSGTONE, DM LOWE, MN MOORE, SV EVANS \& SL MOORE (1982) Response of Mytilus edulis L. on exposure to the water accommodation fraction of North Sea oil. Marine Biology 67: 15-31.

WIDDOWS J, P DONKIN \& SV EVANS (1987) Physiological responses of Mytilus edulis during chronic oil exposure and recovery. Marine Environmental Research 23: 15-32.

WIDDOWS J, KA BURNS, NR MENON, DS PAGE \& S SORIA (1990) Measurement of physiological energetics (scope for growth) and chemical contaminants in mussels (Arca zebra) transplanted along a contamination gradient in Bermuda. Journal of Experimental Marine Biology and Ecology 138: 99-117.

WIDDOWS J, C NASCI \& VU FOSSATO (1997) Effects of pollution on the scope for growth of mussels (Mytilus galloprovincialis) from the Venice Lagoon, Italy. Marine Environmental Research 43: 69-79. 